ISSN: 0213-2060

DOI: https://doi.org/10.14201/shhme20173523762

\title{
DE LOS FUEROS LOCALES AL FUERO DE VALENCIA EN EL MARCO DEL PROCESO DE INSTAURACIÓN DE LA SOCIEDAD FEUDAL DEL SIGLO XIII EN EL REINO DE VALENCIA*
}

\author{
From the local fueros to the Valencia's Fuero in the Context of the Feudal \\ Society Instauration Process at the $13^{\text {th }}$ Century in the Reign of Valencia
}

\author{
Enric GUINOT RODRÍGUEZ \\ Depto. de Història i Ciències i Técniques Historiogràfiques. Facultat de Geografia i Història. Universitat de \\ València. Avda. Blasco Ibáñez, 28. E-46010VALENCIA. C. e.: enric.guinot@uv.es
}

Recibido: 2016-11-09

Revisado: 2017-08-16

Aceptado: 2017-11-03

RESUMEN: Este trabajo analiza el proceso de cambio de los fueros locales a un fuero territorial en el marco del nuevo reino de Valencia creado en 1240 por el rey Jaime I. Siguiendo la tradición de Cataluña y Aragón anteriormente, también en Valencia la corona y la nobleza organizaron inicialmente la repoblación en base a diferentes fueros: Sepúlveda, Zaragoza, Daroca, Teruel, Fontana, costum de Lleida o costum/fuero de Valencia. Pero a partir de 1245, la monarquía impulsó el fuero de Valencia, lo que se ha interpretado tradicionalmente como un motivo político de enfrentamiento entre repobladores catalanes y aragoneses. Nuestro estudio explica cómo el fuero de Zaragoza/Aragón se limitó durante el siglo XIII a unos pocos señoríos, y cómo se generalizó el de Valencia. Por ello el conflicto entre la nobleza de origen aragonés frente al poder público (monarquía y ciudadanos) se inició cuando las primeras cortes de 1261 aprobaron extender el fuero de Valencia como fuero territorial del nuevo reino.

*Este trabajo se inscribe en el Proyecto HAR2014-58730-P, «Crecimiento económico y desigualdad social en la Europa Mediterránea (siglos XIII-XV)», financiado por el Ministerio de Economía y Competitividad del Gobierno de España.

Siglas utilizadas: AHN: Archivo Histórico Nacional, Madrid; ARV: Archivo del Reino de Valencia. 
DE LOS FUEROS LOCALES AL FUERO DE VALENCIA EN EL MARCO DEL PROCESO DE INSTAURACIÓN DE LA SOCIEDAD FEUDAL DEL SIGLO XIII EN EL REINO DE VALENCIA ENRIC GUINOT RODRÍGUEZ

Palabras clave: Ley medieval; Reconquista; Fueros municipales; Fuero de Zaragoza; Fuero de Valencia.

ABSTRACT: This paper analyzes the process of changing local laws (fueros) to a territorial law (fuero) in the context of the new kingdom of Valencia created in 1240 by King James I. Following the tradition of Catalonia and Aragon, also in Valencia the crown and nobility initially organized the repopulation based on different local fueros: Sepúlveda, Zaragoza, Daroca, Teruel, Fontana, costum de Lleida or costum/fuero of Valencia. But from 1245, the monarchy drove the territorial law (fuero) of Valencia, which has traditionally been interpreted as a political reason for confrontation between Catalan and Aragonese populators. Our study explains how the Fuero of Zaragoza/Aragon was limited during the $13^{\text {th }}$ Century to a few seigneuries, and how widespread the Fuero of Valencia. Thus, the conflict between the nobility of Aragonese origin to the public power (monarchy and citizens) began when the first courts of 1261 approved extending the Fuero of Valencia as a territorial law for the new kingdom.

Keywords: Medieval Law; Reconquest; Local Fueros; Fuero of Zaragoza; Fuero of Valencia.

RESUMEN: 0 Introducción. 1 Los planteamientos historiográficos. 2 La concesión de fueros locales en el sur de Aragón y Cataluña entre finales del siglo XII y primer tercio del XIII. 3 Los diversos fueros locales otorgados en tierras valencianas entre 1233 y 1300. 3.1 Los fueros mayoritarios: Costum de Lleida, fuero de Zaragoza y de Valencia. 3.1.1 El fuero de Zaragoza. 3.1.2 El fuero de Valencia. 4 La conflictiva reacción de la nobleza a la territorialización de un fuero regnícola: el Fuero de Aragón frente al Fuero de Valencia (12611329/30). 5 Conclusiones. 6 Referencias bibliográficas.

\section{INTRODUCCIÓN}

Hacia mitad del siglo xIII, en tiempos del rey Jaime I (1213-1276), la Corona de Aragón protagonizó como entidad política un importante cambio en cuanto a sus parámetros jurídicos y organización del poder. Concretamente, en unos pocos años a lo largo de la década de 1240, se sucedieron la promulgación e inicio de la territorialización del Fuero de Valencia, la recopilación del Fuero de Aragón y la revisión de los Usatges en Cataluña. Pero lo cierto es que estos no fueron unos hechos aislados en absoluto y reducidos al ámbito de dicha Corona. En el mismo periodo histórico otros estados medievales europeos recorrieron el mismo camino con mayor o menor éxito, siendo su marco de referencia la recepción del Derecho Romano que se llevaba a cabo desde diversos lugares, principalmente las ciudades y universidades del norte de Italia. Y de ello fue buen ejemplo también la recepción de dicho Derecho en la corona castellano-leonesa del reinado de Alfonso X.

Pero al mismo tiempo, en el marco estricto de la Corona de Aragón, a partir de mitad del siglo XIII esta sociedad, o su élite política, mejor dicho, emprendió el camino 
de otros cambios relevantes en cuanto a la organización del poder público. Tardarían aún en consolidarse dichas transformaciones hasta alrededor del 1300, ya en el reinado de Jaime II, pero municipios, cortes y fueros conformaron en dicha segunda mitad del Doscientos un considerable corpus de cambios que dieron protagonismo político a los sectores sociales ciudadanos y al propio Estado monárquico ${ }^{1}$.

Estas cuestiones han sido tratadas en muchas ocasiones anteriormente, tanto para el conjunto de la Corona de Aragón como para cada uno de los diversos reinos, y con un especial interés por las cuestiones del despliegue foral. Se trata de aportaciones que se remontan incluso a principios del siglo $\mathrm{xx}$, y que han protagonizado tanto historiadores del derecho como medievalistas «strictu sensu», siendo periódicamente además objeto de revisión. Por ello este trabajo va a centrarse en un periodo cronológico relativamente corto, y es el que hace referencia al existente entre los precedentes de la conquista valenciana a principios del siglo xiII y la progresiva territorialización del nuevo Fuero de Valencia a partir de la década de 1250 y los conflictos políticos que generó.

Este planteamiento temático nos va a permitir acercarnos al periodo inicial de construcción de la nueva sociedad feudal valenciana entre 1230 y 1250, aproximadamente, en el cual se otorgó por la corona, nobles y eclesiásticos que dirigieron la repoblación valenciana una diversidad de fueros locales, siguiendo así la tradición de las generaciones anteriores en el sur de Aragón y Cataluña. Se trataría, por tanto, de un periodo histórico de transición de los fueros locales a un fuero de reino, lo que nos permite plantear los problemas de modelo político que se debatieron entre las élites sociales de la Corona de Aragón en el marco de la creación del nuevo reino de Valencia. Y, además, dicho corto periodo cronológico nos va a permitir poder ir con mucha más atención al detalle del seguimiento documental de los diversos fueros otorgados.

Las razones de este enfoque, del paso de la diversidad de fueros locales a la territorialización de un fuero «regnícola» para cada uno de los reinos de la Corona de Aragón de la segunda mitad del siglo XIII, responden justamente a la necesidad de superar unos planteamientos que, en nuestra opinión, deben ser reenfocados. Nos referimos al conflicto político entre la aplicación del Fuero de Aragón y el Fuero de Valencia en este último reino en un sentido «nacional». Es una cuestión de ya larga trayectoria historiográfica, ligada evidentemente al proceso de construcción de la nueva sociedad política valenciana fruto de la creación de dicho reino por Jaime I en 1239, pero al mismo tiempo entremezclada, de forma quizá inevitable, con la cuestión de las identidades actuales de las sociedades catalana, valenciana y aragonesa.

Es por ello conveniente que, como historiadores, intentemos dibujar la fina línea entre la historia y la política contemporánea, pero tampoco deberíamos olvidar que la presencia de la variable presentista no es solo actual, sino que se da ya en épocas anteriores. En este sentido queremos llamar la atención sobre la visión que sobre estas cuestiones de los fueros de Aragón y los fueros de Valencia da un autor clásico, como es Jerónimo

1 Laliena Corbera, Carlos. «La metamorfosis del Estado feudal. Las estructuras institucionales de la Corona de Aragón en el periodo de expansión (1208-1283)». En Sesma MuÑoz, José A. (coord.). La Corona de Aragón en el centro de su historia, 1208-1458: la monarquía aragonesa y los reinos de la corona. Zaragoza: Universidad de Zaragoza, 2010, pp. 67-98. 
DE LOS FUEROS LOCALES AL FUERO DE VALENCIA EN EL MARCO DEL PROCESO DE INSTAURACIÓN DE LA SOCIEDAD FEUDAL DEL SIGLO XIII EN EL REINO DE VALENCIA

Zurita, quizá utilizado demasiado al pie de la letra por algunos historiadores contemporáneos nuestros y que debería ser objeto de una revisión historiográfica en cuanto a su mirada sobre los orígenes del reino de Valencia y su relación con Aragón.

\section{LOS PLANTEAMIENTOS HISTORIOGRÁFICOS}

Este debate entre fueros locales y fueros regnícolas, y entre Fuero de Aragón y Fuero de Valencia, tiene ya tras de sí una considerable tradición historiográfica a lo largo del siglo $\mathrm{xx}$, con predominio en sus primeras décadas de historiadores del derecho, o formados en dicho enfoque, y con un replanteamiento a partir de la década de 1980 hacia el análisis social y económico en cuanto al significado de ser concedido uno u otro fuero. Pero en la gran mayoría de los casos con un claro peso de la cuestión del choque político entre los dos fueros regnícolas, el de Aragón y el de Valencia, asociados a identidades colectivas.

Tal como explicaba en un reciente trabajo Germán Navarro Espinach sobre los fueros de Aragón en la repoblación valenciana ${ }^{2}$, los primeros acercamientos claramente con perfil histórico se remontan a principios del siglo xx y su objetivo era estudiar la génesis de los fueros valencianos. Este fue el planteamiento del que, creo, podemos considerar primer acercamiento académico: la obra del canónigo Roque Chabás del año 1902 sobre la génesis del fuero de Valencia ${ }^{3}$. Un trabajo que influyó claramente en el planteamiento de Santiago Cebrián Ibor en $1925^{4}$, con pocas novedades respecto al anterior, y en el de Juan Beneyto , historiador del derecho, quien se centró en la territorialización de dicho fuero valenciano. Con posterioridad a la Guerra Civil, esta línea de base jurídica continuó con la edición de un primer manuscrito del Fuero de Valencia por Manuel Dualde en el año 1950, y sobre todo con el estudio de Miguel Gual Camarena, centrado en el mismo planteamiento sobre la presencia territorial de uno u otro fuero en la Valencia bajomedieval, y ello a partir de un seguimiento del fuero otorgado en las cartas pueblas, textos que dicho autor recopilaba en aquel momento ${ }^{6}$.

En nuestra opinión estos dos últimos trabajos son los que influyen directamente en el decantamiento de los estudios de las décadas siguientes de 1960 y 1970 sobre el concepto del dualismo en los orígenes del reino valenciano medieval y de las características de su sociedad, de influencia catalana o aragonesa, y con un reparto de los pueblos y

2 Navarro Espinach, Germán. «Los fueros de Aragón en la repoblación valenciana». En Los fueros de Teruel y Albarracin: Actas de las Jornadas (1998). Teruel: Instituto de Estudios Turolenses, 2000, pp. 59-75.

3 Chaвás, Roque. Génesis del derecho foral de Valencia. Valencia: Imprenta de F. Vives Mora, 1902, reeditado en Chaвás, Roque. Opúsculos. Valencia: Consell Valencià de Cultura, 1995, pp. 87-220.

4 Cebrián Ibor, Santiago. "Los fueros de Valencia». En III Congreso de Historia de la Corona de Aragón. Valencia: Ajuntament de Valencia, 1923, t. 1, pp. 605-665.

5 Beneyto Pérez, Juan. «Sobre la territorialización del código de Valencia». Boletín de la Sociedad Castellonense de Cultura, 1934, vol. XII, pp. 187-197.

6 Dualde Serrano, Manuel. Fori Antiqui Valentiae. Edición crítica. Madrid-Valencia: Consejo Superior de Investigaciones Científicas, 1950-1967; Gual Camarena, Miguel. «Contribución al estudio de la territorialidad de los fueros de Valencia». Estudios de Edad Media de la Corona de Aragón, 1947-1948, vol. 3 , pp. 262-289. 
comarcas valencianas entre una u otra. Una sociedad medieval dual, de origen catalán y burgués en las ciudades y la costa, y otra de origen aragonés y señorial en el interior rural, tal como se apuntaba en el trabajo de M. Gual, pero que fueron llevados a una generalización con espíritu de modelo social en los trabajos de Joan Fuster y Joan Reglà en la década de 1960, y de Ernest Belenguer en la de $1970^{7}$.

El peso de dicho modelo explicativo, en buena medida basado en la diferencia de interpretación del valor simbólico de uno y otro fuero, que no en la real comparación detallada de su contenido político, social y jurídico, ha dejado un largo rastro en la historiografía de la Corona de Aragón, especialmente en la valenciana, en cuanto al relato de la repoblación y creación del nuevo reino medieval de Valencia. De ahí el camino recorrido por algunos autores de finales de la década de 1970 y la de 1980, caso de Antonio Ubieto,

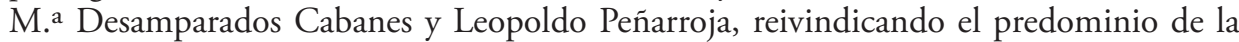
repoblación aragonesa en la Valencia del siglo XIII, minimizando la migración de pobladores desde Cataluña o imaginando un mundo andalusí del 1200 pletórico de mozárabes y/o con una población musulmana que desconocía el árabe ${ }^{8}$.

Con todo, y de forma paralela, también en las décadas de 1970 y 1980 se desarrolló una línea dirigida al estudio más jurídico de la génesis del fuero de Valencia, con un protagonismo de nuevo por parte de historiadores del derecho. Probablemente el antecedente esté en los trabajos de Honori García de los años $1940^{9}$, y también en los estudios de derecho local en Cataluña de José M. ${ }^{a}$ Font Rius y su recopilación de cartas pueblas. Es así como podemos entender mejor la aproximación de Arcadio García Sanz al tema ${ }^{10}$, así como su colaboración con Germà Colón para la edición de los Fueros de Valencia en diez volúmenes, si bien en los últimos de ellos con intervención de Vicent García Edo ${ }^{11}$. En estos casos encontramos una argumentación centrada en identificar las

Fuster, Joan. Nosaltres els valencians. Barcelona: Edicions 62, 1962; ReGLÀ, Joan. «El dualismo en Valencia y sus desequilibrios». Saitabi, 1967, vol. XVII, pp. 51-70; RegLì, Joan. Aproximació a la història del País Valencià. Valencia: L'Estel, 1968; Belenguer Cebrià, Ernest. «En torno a la sugestiva tesis de Joan Reglà: el dualismo valenciano y sus desequilibrios». Boletín de la Real Academia de la Historia, 1977, vol. CLXXIV, pp. 141-171.

8 Pueden servir de referencia algunos trabajos de Ubieto Arteta, Antonio. Orígenes del Reino de Valencia. Valencia: Editorial Anúbar, 1975-1977, 2 vols.; Cabanes Pecourt, M. ${ }^{a}$ Desamparados. «Aspectos demográficos de la conquista: población preexistente y repoblación en la ciudad de Valencia». En En torno al 750 aniversario. Valencia: Generalitat Valenciana, 1989, t. 1, pp. 303-318; ÍDEM. «El barrio de Zaragoza y los zaragozanos en la repoblación valenciana». Aragón en la Edad Media, 2011, vol. 22, pp. 49-66; ÍDEM. "Tarazona en la repoblación valenciana de 1239». Aragón en la Edad Media, 1987, vol. 7, pp. 39-46; PeñarrojA, Leopoldo. Cristianos bajo el Islam. Los mozárabes hasta la reconquista de Valencia. Madrid: Gredos, 1993.

9 García García, Honori. «Los Fueros de Valencia y la "Costum" de Tortosa». Boletín de la Sociedad Castellonense de Cultura, 1933, vol. XIV, pp. 326-332.

10 García Sanz, Arcadi. «La concordança de les Costums de Tortosa i els Furs de València». En Costums de Tortosa. Estudis. Tortosa: UNED, 1979, pp. 289-325; ÍDEM. «Las "Consuetudines ilerdenses" y los "Furs" de Valencia». Boletin de la Sociedad Castellonense de Cultura, 1965, vol. XLI, pp. 1-26; ÍDEM. «Les fonts del dret valencià i les corts forals». En Les Corts Forals Valencianes: poder i representació. Valencia: Generalitat Valenciana, 1994, pp. 38-65.

11 Colón, Germà y García SAnZ, Arcadi. Furs de València. 8 vols. Barcelona: Editorial Barcino, 1970-1998; Colón, Germà y García Edo, Vicente. Furs de València. Vol. 9, Barcelona: Editorial Barcino, 2002; Colón, Germà y ABAD, Isabel. Furs de València. Vols. 10 y 11. Barcelona: Editorial Barcino, 2007. 
DE LOS FUEROS LOCALES AL FUERO DE VALENCIA EN EL MARCO DEL PROCESO DE INSTAURACIÓN DE LA SOCIEDAD FEUDAL DEL SIGLO XIII EN EL REINO DE VALENCIA

fuentes jurídicas de dichos fueros valencianos en su redacción original del siglo XIII, en la recepción del Derecho Común, especialmente a partir del Código de Justiniano, y en la relación que tenían con las Costums de Lérida y Tortosa, tal como se ha desarrollado en diversos trabajos de dichos autores y también especialmente en los de Mariano Peset $^{12}$. Se trata de un planteamiento que tuvo también aportaciones de otros autores, caso de Ana M. ${ }^{a}$ Barrero, Aquilino Iglesias, Gonzalo Martínez Díez y Juan García González ${ }^{13}$ y especialmente por parte de V. García Edo ${ }^{14}$, los cuales hacen comparaciones en cuanto al contenido de los tres códigos. A ellos cabe ańadir los posteriores trabajos del citado García Edo sobre la datación del costum de Valencia, texto original del futuro Fuero de Valencia ${ }^{15}$, así como de Pedro López Elum sobre su génesis en tiempos de Jaime $\mathrm{I}^{16}$, ambos con un perfil más histórico y jurídico y con un detallado seguimiento documental. En todo caso ha sido el primero de estos dos últimos quien ha continuado con el tema en los últimos años, aportando nuevos trabajos sobre el derecho local valenciano o sobre la implantación territorial del fuero de Valencia ${ }^{17}$.

Un planteamiento diferente de la cuestión fue el iniciado por Enric Guinot en 1983 al centrarse en las diferencias de rentas señoriales fijadas en las cartas de población del siglo XIII concedidas a fuero de Zaragoza-fuero de Aragón frente a las otorgadas a fuero de Valencia. Se trata de una cuestión retomada por Ramón Ferrer en $1989^{18}$, y que pretendió desmontar la visión dualista de la nueva sociedad valenciana a partir de la repoblación catalana y aragonesa, justamente poniendo en evidencia que en la región de Castellón los niveles de rentas fijados para los lugares repoblados a fuero de Zaragoza fueron en general

12 Peset Reig, Mariano. «Observaciones sobre la génesis de los fueros de Valencia y sobre sus ediciones impresas». Ligarzas, 1971, vol. 3, pp. 47-84; ÍDEM. «De nuevo sobre la génesis de los fueros de Valencia». Anales del Seminario Metropolitano de Valencia, 1971, vol. 16, pp. 395-413; ÍDEM. «Furs de Valencia: su sentido y vigencia». En En torno al 750 aniversario, t. 1, pp. 361-378.

13 Barrero Sanz, Ana M. ${ }^{a}$. «El derecho Romano en los Furs de Valencia de Jaime I». Anuario de Historia del Derecho Español, 1971, vol. 41, pp. 639-664, y en 1r Congreso de Historia del País Valenciano. Valencia: 1971, t. 2, pp. 471-478; Iglesia Ferreirós, Aquilino. «Las Costums de Tortosa y los Fori/Furs de Valencia». En Costums de Tortosa. Estudis, pp. 119-286; Martínez Díez, Gonzalo. "Los fueros valencianos en relación con otros fueros coetáneos». En En torno al 750 aniversario, t. 1, pp. 379-394; GARCíA GonZÁLEZ, Juan. «Las fuentes de los fueros de Valencia». En En torno al 750 aniversario, t. 1, pp. 345-360.

14 García Edo, Vicente. «El parentesco entre las costumbres de Lérida (1228), Valencia (1238) y Tortosa (1273)». Anuario de Historia del Derecho Español, 1997, vol. 67, pp. 173-188.

15 García Edo, Vicente. "La redacción y promulgación de la "Costum” de Valencia». Anuario de Estudios Medievales, 1996, vol. 26, n.o 2, pp. 713-728; ÍDEM. "Origen i expansió dels Furs o Costum de València, durant el regnat de Jaume I». Boletín de la Sociedad Castellonense de Cultura, 1993, vol. 69, pp. 175-200.

16 López Elum, Pedro. Los orígenes de los Furs de València y de las Cortes en el siglo XIII. Valencia: Biblioteca Valenciana, 2001; ÍDEM. «La costum, els furs y las cortes». En Jaume I, legislador. El reino de Valencia. Valencia: Generalitat Valenciana, 2008, pp. 167-182.

17 García Edo, Vicente. «Els orígens del dret municipal al Regne de València (1232-1284)». En SERrano Daura, Josep (coord.). Actes de les Jornades d'Estudi sobre el municipi abans de la Nova Planta (1716). El cas de la Fatarella. Tarragona: Diputació de Tarragona, 2013, pp. 189-204; ÍDem. "Orígenes del derecho foral valenciano». Revista Valenciana d'Estudis Autonomics, 2008, vol. 51, pp. 147-161.

18 Guinot Rodríguez, Enric. «El problema de la renta feudal y los fueros. Un análisis de las cartas puebla del siglo XiII en el norte de Castellón». Saitabi, 1983, vol. XXXIII, pp. 59-83; Ferrer Navarro, Ramón. "El fuero de Aragón y la pretendida dualidad valenciana». Aragón en la Edad Media, 1989, vol. VIII, pp. 257-270. 
más bajos que en los lugares poblados a costum de Lleida o fuero de Valencia, lo que implicaba que en dichos lugares de interior no se había instaurado un señorío más exigente con los vasallos. Además, ello no se debía al origen «nacional» de dichos repobladores campesinos sino a la diferente tradición jurídica del noble que otorgaba el fuero en unos años de transición previos a la promulgación del Fuero de Valencia, hechos en los que además tuvo un claro protagonismo numérico el noble Blasco de Alagón y su peculiar acceso al seńorío del término general de Morella y adyacentes en la década de $1230^{19}$.

Finalmente, las revisiones más recientes de la cuestión foral se han enmarcado de nuevo en el conflicto político que representó la aplicación de ambos fueros durante el primer siglo de existencia del nuevo reino valenciano, entre 1238 y 1330, aproximadamente. En estos trabajos de V. García Edo y Vicent Baydal se han planteado nuevos enfoques sobre el conflicto entre la nobleza aragonesa, por un lado, y la corona y los ciudadanos de Valencia, por otro, especialmente durante el reinado de Pedro III. Se trata del periodo en que se organizó políticamente la primera Unión aragonesa, y que perduró hasta las cortes de Valencia de 1329/30, en las que se promulgó la llamada «jurisdicción alfonsina» y que marcaron un cierto final para dicha pugna entre los dos fueros en Valencia, tal como planteó en su momento Sylvia Romeu y ha revisado V. Baydal ${ }^{20}$.

Llegados, pues, a este punto, nuestra aportación va a centrarse en explicar el contexto histórico de conquista y repoblación durante las décadas de 1230 y 1240 como motor de las diferencias en la concesión de los diversos fueros locales en tierras valencianas, sin que en ello hubiese una causa profunda de carácter «nacional», aragonesa o catalana, y cómo se dio a continuación el paso político a la territorialización de un fuero "regnícola». Y para ello debemos empezar revisando cómo se concedían los fueros locales en el sur de Aragón y Cataluña justo antes de la conquista de Valencia a partir de 1233.

\section{La concesión de fueros locales en el sur de Aragón y Cataluña entre fina- LES DEL SIGLO XII Y PRIMER TERCIO DEL XIII}

Durante el siglo anterior a la conquista cristiana de Valencia, la Corona de Aragón se había expandido militarmente por el sur de Aragón y Cataluña. Como es bien sabido, en las décadas en torno al 1200 ninguno de los dos reinos o territorios tenía una legislación unificada, sino que los fueros y normas locales dominaban aún el paisaje jurídico de ambos territorios, aunque las diferencias entre ellos fuesen notables.

19 García Edo, Vicent. «Blasco de Alagón». Boletín de la Sociedad Castellonense de Cultura, 1986, vol. LXII, pp. 383-420; ÍDEM. "Nuevas aportaciones documentales sobre don Blasco de Alagón». Boletín de la Sociedad Castellonense de Cultura, 1989, vol. LXVI, pp. 287-301.

20 Baydal, Vicent. Els valencians, des de quan són valencians? Barcelona-Catarroja: Editorial Afers, 2016; García Edo, Vicent. "Aragón contra Valencia: la disputa foral durante el reinado de Pedro III de Aragón». En Agost, Rosa y Gimeno, Lluís (eds.). Homenatge a Germà Colón Domènech. Castelló: Universitat Jaume I, 2014, pp. 65-102; ÍDEM. «El Privilegium Magnum del rey Pedro I como acta de salvaguarda del reino de Valencia frente a las intromisiones aragonesas de 1283». Revista Valenciana d'Estudis Autonòmics, 2015, vol. 60, pp. 10-62; Romeu Alfaro, Sylvia. «Los fueros de Valencia y los fueros de Aragón: la jurisdicción alfonsina». Anuario de Historia del Derecho Español, 1972, vol. 42, pp. 75-115. 
DE LOS FUEROS LOCALES AL FUERO DE VALENCIA EN EL MARCO DEL PROCESO DE INSTAURACIÓN DE LA SOCIEDAD FEUDAL DEL SIGLO XIII EN EL REINO DE VALENCIA ENRIC GUINOT RODRÍGUEZ

Se trata de una temática bien conocida y en la que, entre otras cuestiones, se ha puesto en evidencia la sucesión de fueros o costumbres locales que caracterizaban dicho periodo histórico, unas veces bajo la forma de fueros breves y en otras bajo la de fueros extensos. Tal como estudió entre otros el profesor Jesús Lalinde ${ }^{21}$, existieron diversas «familias» de fueros de norte a sur de Aragón: fueros de francos o burgueses, ejemplificados en el fuero de Jaca; fueros de Sobrarbe o de infanzones, como el de Barbastro y posteriormente el mucho más difundido de Zaragoza; y fueros de extremadura o concejiles ya en la zona meridional, caso de los de Calatayud, Daroca, Teruel y Albarracín ${ }^{22}$. Por su parte, además de las abundantes ordenaciones locales en Cataluña estudiadas durante años por J. M. ${ }^{a}$ Font Rius ${ }^{23}$ y en la última época por Tomás de Montagut ${ }^{24}$, los casos más relevantes por su relación con el futuro reino valenciano son las conocidas costums de Lérida y de Tortosa, aunque la realmente consolidada en aquellos años fuese la primera de ellas ${ }^{25}$.

Limitándonos aproximadamente al último medio siglo antes de la conquista de la ciudad de Valencia en 1238, el proceso de repartimiento y/o fundación de villas y lugares para los pobladores cristianos de ambas regiones de Teruel y Tortosa comportó un mismo mecanismo. La concesión individual a cada lugar, por parte del seńor respectivo o de la corona, de una carta puebla que regularía a partir de entonces las relaciones sociales, económicas y jurídicas de la nueva comunidad, tanto entre sí como con respecto al poder señorial respectivo. Y es en ellas donde se incluye de forma habitual, aunque no siempre, la referencia al fuero con el que se regulará jurídicamente la nueva comunidad de pobladores, tal como ha estudiado M. ${ }^{a}$ Luisa Ledesma en diversas aportaciones sobre ellas ${ }^{26}$.

21 Lalinde Abadía, Jesús. Los Fueros de Aragón. Zaragoza: Librería General, 1976.

22 Barrero Sanz, Ana M. ${ }^{\mathrm{a}}$. "Los fueros de Teruel y Albarracín (apunte historiográfico)». En Los Fueros de Teruel y Albarracín. Teruel: Instituto de Estudios Turolenses, 2000, pp. 269-279; Corral Lafuente, José L. «El impacto social de los fueros de la Extremadura aragonesa». En Los Fueros de Teruel y Albarracín, pp. 19-30; Delgado Echeverría, Jesús. Los Fueros de Aragón. Zaragoza: Caja de Ahorros de la Inmaculada, 1997; Iranzo, M. ${ }^{a}$ Teresa. "La formación del Derecho local de Huesca y los fueros de Aragón». Aragón en la Edad Media, 1989, vol. 8, pp. 337-350; Morales, Jesús. Fueros y libertades del Reino de Aragón: de su formación medieval a la crisis preconstitucional (1076-1800). Zaragoza: Rolde de Estudios Aragoneses, 2007; Morales, Jesús. «La formación bajomedieval del sistema aragonés de fueros y observancias». En La Corona de Aragón en el centro de su historia: 1208-1458: la monarquía aragonesa y los reinos de la Corona. Zaragoza: Universidad de Zaragoza, 2010, pp. 353-394.

23 Font Rius, José M.a. Cartas de población y franquicia de Cataluña. 2 vols. Madrid-Barcelona: Consejo Superior de Investigaciones Científicas, 1969-1983, especialmente el segundo volumen. ÍDEM. «La potestat normativa del municipi català medieval». En Miscel.lània Ramon d'Abadal. Barcelona: Estudis Universitaris Catalans, 1994, pp. 131-164.

24 Montagut, Tomàs de. «Ordenamientos jurídicos locales catalanes». Revista de Historia Jerónimo Zurita, 2003-2004, vol. 78-79, pp. 153-178; ÍDEM. «Comunidades locales en Cataluña y su derecho medieval». Vasconia: Cuadernos de historia-geografía, 2009, vol. 36, pp. 5-18; ÍDEm. «Les universitats de les ciutats i viles medievals de Catalunya i el seu dret: dels usos, costums, privilegis i llibertats a les ordinacions municipals». En Serrano Daura, Actes de les Jornades d'Estudi sobre el municipi abans de la Nova Planta, pp. 25-38; ÍDem. «Derecho municipal y derecho común: el caso de Cataluña». En Serna, Margarita y Baró, Juan (coords.). El fuero de Laredo en el octavo centenario de su concesión. Santander: Universidad de Cantabria, 2001, pp. 517-534.

25 García EDo, «El parentesco entre las costumbres de Lérida (1228), Valencia (1238) y Tortosa (1273)».

26 Ledesma Rubio, M. ${ }^{a}$ Luisa. "Las cartas de población aragonesas y su remisión a los fueros locales: La problemática del fuero de Zaragoza». Ius fugit: Revista Interdisciplinar de Estudios Histórico-jurídicos, 1992, 
Esta autora ha explicado el claro predominio de la concesión del fuero de Zaragoza en la mitad sur del reino aragonés justamente en las décadas alrededor del 1200, durante la generación anterior a la conquista de Valencia. Pero también después de esta, cuando continuó la repoblación de las comarcas turolenses más cercanas al nuevo reino de Valencia, por tierras de la actual provincia de Castellón. Aunque no es exhaustivo, la revisión del listado de cartas pueblas aragonesas, que dicha profesora publicó en 1991, referido al periodo entre los años 1195 y 1247, hasta la promulgación primera del llamado Fuero de Aragón, nos aporta 35 localidades que recibieron dicho documento, pues no todas las que incluye en su colección son en realidad verdaderas cartas puebla. En veinticuatro sí se indica la concesión de un fuero jurídico y de ellas 17 corresponden al fuero de Zaragoza, bien directamente, bien por ser una aldea o lugar y remitirse al fuero de la villa principal del distrito, caso de La Cuba (1241) y Mirambel (1243) con respecto a la villa de Cantavieja. Los otros casos son el fuero de Daroca, el fuero de Ejea de los Caballeros, el fuero de Huesca y el fuero de Berbegal, o bien un fuero breve propio, caso de Montalbán o Aliaga.

Lo que observamos es que la concesión de estos otros fueros corresponde en general a poblaciones situadas más al norte y que, dado que se trata de poblaciones pequeñas, todo apunta a que se concede el fuero de la villa importante o cabecera de distrito de su entorno. Esto es lo que pasa con la rebautizada Salvatierra en término de Ejea de los Caballeros, o con la pequeña aldea de Las Pedrosas en el término de Loporzano y el fuero de Huesca. Pero realmente, entrados en el siglo xiII, y por tanto enlazando con el tiempo de la conquista y repoblación de las tierras valencianas, fue general la concesión del fuero de Zaragoza. Y ello tanto por señores laicos: Rodrigo de Bolea en Calaceite (1207), el linaje San Pedro en La Fresneda (1224), Bernardo Rey y otros en Fuentespalda (1232); como por monasterios: monasterio de Rueda: Jaulín (1217), Lagata (1220), Samper de Lagata (1229), La Senia (Belchite) (1235); el monasterio de Veruela: Alcalá de Moncayo (1238), Pozuelo, término de Rueda (1245) y Villamayor (1246). Y también las órdenes militares: orden del Temple: Villarluengo (1197), Libros (1212), Cantavieja (1225), La Cuba y La Iglesuela (1241), Mirambel (1243); la orden de Calatrava en Belmonte (1232) y la orden del Hospital en Caspe (1254) ${ }^{27}$.

Por su parte, en el caso del sur de la Cataluña Nueva, en el mismo periodo cronológico alrededor del $1200 \mathrm{y}$ hasta mitad del siglo xiII, las cartas pueblas concedidas hacen referencia muy mayoritariamente a la costum de Tortosa y, en menor medida, a otros derechos locales, caso del fuero de Horta. Tal como estudió en su momento Font Rius, toda la comarca del Baix Ebre, en parte situada dentro de los términos generales de la ciudad de Tortosa, fue poblada con dicha referencia, o a la paralela del castillo de Ulldecona por parte tanto de la orden del Hospital como de caballeros de la ciudad: Fullola (1208), Vallcanera (1238), Rafalgarí (1242), Font de l'Ametlla (1227), Avencalles (1257), La

\footnotetext{
vol. 1, pp. 63-78; ÍDEM. Cartas de población del Reino de Aragón en los siglos medievales. Zaragoza: Institución Fernando el Católico, 1991; ÍDEM. «Las "cartas de población” medievales como fuentes de investigación». En II Jornadas de metodología de la investigación cientifica sobre fuentes aragonesas. Zaragoza: 1987, pp. 125-168; Í DEM. Cartas de población y fueros turolenses. Teruel: Instituto de Estudios Turolenses, 1988.

27 Todas las referencias documentales son de la colección de cartas pueblas aragonesas de M. ${ }^{a}$ Luisa Ledesma más arriba citada, en la fecha y localidad señaladas.
} 
DE LOS FUEROS LOCALES AL FUERO DE VALENCIA EN EL MARCO DEL PROCESO DE INSTAURACIÓN DE LA SOCIEDAD FEUDAL DEL SIGLO XIII EN EL REINO DE VALENCIA

Cénia (1236), Godall (1238), Mas de Barberans (1235) y La Rápita (1251). Por su parte, en la comarca vecina de la Terra Alta, con un gran señorío de la orden del Temple, dicha orden fue poblando Gandesa (1192 y 1194), Pinell (1198 y 1207), Batea (1205), Villalba (1224), Valle de Batea (1244), Camposines (1209), Gorrapte (1237) y Gandesola (1248), que en su mayoría remiten a un "fuero de Horta», referido a las condiciones de la puebla de dicha villa templaria de Horta de Sant Joan del año 1190. Por otro lado, y tal como explica dicho autor, en cambio no hay un uso del fuero de Zaragoza en estas comarcas meridionales catalanas en dicha época. Aunque sí lo hubo anteriormente, en las décadas de 1160 y 1170 y para lugares al sur del río Ebro, lo cierto es que dicho fuero no tuvo continuidad en la región meridional catalana ${ }^{28}$.

En resumen, y en nuestra opinión, cuando se inició la conquista de Valencia en 1233, evidentemente no existían aún los fueros regnícolas como referencia jurídica de las fundaciones de nuevas poblaciones, ni en Aragón ni en Cataluña. Pero tampoco existía un modelo único de concesión de fuero local por parte de los diversos poderes políticos: tanto por parte de las órdenes militares, con mayor presencia en estas regiones fronterizas con lo que iba a ser el nuevo reino de Valencia, como por parte de nobles o monasterios. Sí parece claro que en el sur de la región aragonesa el triunfador era el fuero de Zaragoza, pero hay suficientes excepciones a principios del siglo XIII como para constatar que la clase nobiliaria podía actuar por criterios particulares. Y en el caso del sur de Cataluña, dada su menor extensión superficial en las cercanías de las tierras valencianas, el peso del territorio de la ciudad de Tortosa parece determinante, pero el caso de la orden del Temple nos evidencia que asimismo prevalecía su autonomía política. Así pues, este sería el contexto con el que empezaría la repoblación valenciana.

3 LOS DIVERSOS FUEROS LOCALES OTORGADOS EN TIERRAS VALENCIANAS ENTRE 1233 Y 1300

En primer lugar, debemos recordar que el reino de Valencia bajomedieval no existía como tal en el momento de iniciarse la primera campaña de conquista por parte de Jaime I en 1233. Tal como hemos estudiado en otros lugares, el título de rey de Valencia que adoptó dicho monarca al conquistar la ciudad en septiembre de 1238 hacía referencia al territorio que controlaba Zayyan ibn-Mardanis en aquel momento, esto es, la región en torno a dicha capital, pero no las comarcas actuales de Castellón y mucho menos las situadas al sur del río Júcar ${ }^{29}$. Sería tan solo a partir de la concesión del Fuero de Valencia cuando, en un preámbulo no datado, se indican unos límites que iban del río de la Cenia al norte hasta la localidad de Biar, en la montańa alicantina. Por tanto, el punto de partida de la concesión de fueros en la década de 1230 es el de un contexto local. Y por ello el proceso de otorgamiento de fueros se produjo de la misma manera que acabamos

28 Font Rius, Cartas de población y franquicia, vol. II, pp. 199-205, donde da las referencias documentales y de publicación de los respectivos textos, a los que nos remitimos.

29 Guinot Rodríguez, Enric. Els limits del Regne. El procés de formació del País Valencià medieval (1238-1500). València: Institució Alfons el Magnànim, 1995. 
de ver para las vecinas regiones del sur de Aragón y Cataluña, teniendo como parámetros iniciales el proceso de conquista y el inmediato repartimiento del territorio.

Recordemos, pues, que el proceso de conquista fue dirigido entre 1233 y 1245 por el rey Jaime $\mathrm{I}^{30}$, y por ello fue la corona la que llevó a cabo el repartimiento del territorio del Sarq al-Ándalus, tal como se ha estudiado en diversas ocasiones ${ }^{31}$. La consecuencia es que el monarca concedió a la nobleza, eclesiásticos y órdenes militares términos castrales, villas y alquerías, pobladas o no, todos los cuales, por el hecho de dicha donación, se convirtieron en propiedad de dicha clase social y, por tanto, en la práctica, en señoríos territoriales. Para esto último era necesario disponer de vasallos y, en el marco de la repoblación del nuevo reino de Valencia creado entre 1239 y 1240, en unos casos se mantuvo la población andalusí preexistente, con mayor o menor alteración y cambio de su carácter local por haber migraciones y expulsiones. Pero en otros casos, por despoblación en el contexto de la conquista o por expulsión forzada en esos años o posteriores durante el siglo XIII, los nuevos señores de la tierra procedieron a poblar sus respectivos seńoríos con migrantes cristianos de Cataluña y Aragón, básicamente familias campesinas ${ }^{32}$.

Es en este contexto en el que individualmente cada noble, o en su caso el monarca, repoblaron cada término, pueblo o señorío, y el instrumento jurídico general para ello fue la concesión de una carta puebla. Han sido y aún son un objeto de estudio tradicional desde diversos aspectos históricos, y actualmente disponemos de una colección publicada de ellas bastante amplia, por lo que podemos utilizarlas de forma práctica $^{33}$. Y es en ellas donde de forma también casi general los nuevos señores incluyeron una cláusula referida al ordenamiento jurídico que iba a regular las relaciones sociales, políticas

30 Torró, Josep. «Jaume I i la formació del regne de València. Una perspectiva general». En CoLón, Germà y Martínez Romero, Tomàs (eds.). El rei Jaume I. Fets, actes i paraules. Castelló-Barcelona: Fundació Germà Colón-Abadia de Montserrat, 2008, pp. 13-32; ÍDEm. "Jaume I: el temps de les grans conquestes (1213-1276)». En Belenguer, Ernest (dir.). Història de la Corona d’Aragó. Barcelona: Edicions 62, 2007, vol. I, pp. 117-122; López Elum, Pedro. «La conquista de Valencia». En Història del País Valencià. Barcelona: Edicions 62, 1989, vol. 2, pp. 57-124.

31 Torró, Josep. «Guerra, repartiment i colonització al regne de València (1248-1249)». En GuINOT Rodríguez, Enric y Torró, Josep (eds.). Repartiments medievals a la Corona d'Aragó: segles XII-XIII. València: Universitat de València, 2007, pp. 197-270; ÍDEM. El naixement d'una colònia. Dominació $i$ resistència a la frontera valenciana (1238-1276). València: Universitat de València, 1999; Ídem. La formació d'un espai feudal. Alcoi de 1245 a 1305. València: Diputació de València, 1992; Guinot Rodríguez, Enric. «El repartiment feudal de l'Horta de València al segle xiIr: jerarquització social i reordenació del paisatge rural». En Guinot Rodríguez y Torró (eds.), Repartiments medievals a la Corona d'Aragó, pp. 111-196; Ídem. Los valencianos de tiempos de Jaime I. Valencia: Ed. Tirant lo Blanc, 2011; Furió, Antoni. «Organització del territori i canvi social al País Valencià després de la conquesta cristiana». En Territori i Societat a l'Edat Mitjana. Lleida: Universitat de Lleida, 1997, t. I, pp. 131-166.

32 Guinot Rodríguez, Enric. "La implantació de la societat feudal al País Valencià del segle xiII: la gènesi de les senyories i l'establiment de les terres». En Sabaté i Curull, Flocel y Farré, Joan (coords.). El temps i l'espai del feudalisme. Lleida: Pagès Eds., 2004, pp. 421-442; Garcia-Oliver, Ferran. Terra de feudals. El País Valencià en la tardor medieval. València: Institució Alfons el Magnànim, 1991.

33 Guinot Rodríguez, Enric. Cartes de poblament medievals valencianes. Valencia: Generalitat Valenciana, 1991; ÍDEM. «Fueros y ordenamientos jurídicos locales en la Valencia medieval». Revista de Historia Jerónimo Zurita, 2004, vol. 78-79, pp. 203-227. En realidad, el título de este trabajo era «Ordenamientos jurídicos locales valencianos», pero por una incomprensible errata editorial apareció con el título general del coloquio. 
DE LOS FUEROS LOCALES AL FUERO DE VALENCIA EN EL MARCO DEL PROCESO DE INSTAURACIÓN DE LA SOCIEDAD FEUDAL DEL SIGLO XIII EN EL REINO DE VALENCIA ENRIC GUINOT RODRÍGUEZ

y jurídicas de los repobladores que se asentaran en el lugar. Por tanto, tal como había sucedido en el sur de Aragón y de Cataluña durante la segunda mitad del siglo xII y el primer tercio del XIII, también en el nuevo reino valenciano la concesión de los fueros en el marco de la repoblación del siglo XIII tuvo un carácter local.

Los fueros concedidos a lo largo del siglo XIII en tierras valencianas fueron diversos y han sido enumerados y detallados en diversas ocasiones por M. Gual, A. García Sanz y G. Colón, E. Guinot, V. García Edo o G. Navarro entre otros, trabajos ya citados a los que remitimos para mayores detalles. El resumen por orden cronológico de aparición sería el siguiente en cuanto a su primera concesión:

\begin{tabular}{|l|c|l|}
\hline Fuero de Sepúlveda & 1233 & Morella \\
\hline Fuero de Zaragoza & 1233 & Burriana \\
\hline Costum de Lérida & 1235 & Cervera \\
\hline Fuero de Teruel & 1238 & Jérica \\
\hline Fuero de Fontana & 1239 & Benimahomet (Castellón) \\
\hline Costum de Valencia & 1239 & Valencia \\
\hline Fuero de Daroca & 1243 & Villamalefa/Villahermosa \\
\hline
\end{tabular}

A estos fueros cabe añadir el uso en diversas ocasiones de referencias indirectas al fuero de la villa cercana en la que se encuentra la nueva población o a fórmulas indirectas que remiten a la Costum de la ciudad de Valencia. Este es el caso del lugar de Moncófar, que recibió en 1254 el de la villa de Nules, o el de Peníscola bajo la forma secundum quod omnibus civitatis Valentie fecimus en 1251, y algunos otros similares que explica V. García Edo ${ }^{34}$.

En cuanto a la concesión de los fueros de Toledo, Córdoba, etc., a las villas de Orihuela, Alicante y Elche durante el siglo xiII, y el de Cuenca a la villa de Ayora, tal como recordaba en su trabajo G. Navarro, debemos tener en cuenta que en ese siglo, hasta 1281 (Ayora) y 1296 (el resto), pertenecieron al reino castellano, recibiendo en 1308 los Fueros de Valencia por concesión de Jaime II el grupo de las villas alicantinas ${ }^{35}$. Aunque, sin duda, ello es relevante para la historia política de los siglos XIV y XV, teniendo en cuenta esa diferencia de reino, creemos que en este estudio sobre el paso de los fueros locales al fuero territorial es mejor no introducir dicha variable por no ser relevante para el reino de Valencia de Jaime I del siglo XIII.

Asimismo, no debe incluirse entre estos fueros el llamado costum de Barcelona, que es citado por diversos autores equiparándolo a los anteriores. Es un grave error de interpretación, ya que en realidad hace referencia a la relación feudal entre la corona y el noble que recibía un castillo y su territorio en el marco del repartimiento y donaciones que hizo Jaime I y sus sucesores a lo largo del siglo XIII. Dicha costum de Barcelona regulaba, pues, los derechos del noble sobre el castillo, el homenaje que debía este al monarca y el reconocimiento de la potestad en favor del rey.

34 García Edo, «Origen i expansió dels Furs», pp. 183-186.

35 Estal, Juan Manuel del. Documentos inéditos de Alfonso X el Sabio y del Infante, su hijo, don Sancho. Alicante: 1984; ÍDEm. Libro de los primitivos privilegios de Alfonso X el Sabio a Alicante. Estudio histórico-crítico yed. facsimil. Madrid: EDILAN, 1984. 
Así, pues, el listado de fueros concedidos en los orígenes del reino de Valencia son los siete del cuadro anterior, si bien no todos ellos tuvieron el mismo significado. De entrada debemos separar cuatro de ellos: Sepúlveda, Fontana, Teruel y Daroca, pues tan solo se concedieron una vez $y$, realmente, se pueden entender en un contexto bien peculiar y aislado.

El de Sepúlveda fue el que otorgó el 17 de abril de 1233 el noble Blasco de Alagón, mayordomo real de Aragón, al castillo y villa de Morella. Su carta puebla estaba redactada en los términos y con los apartados habituales en otros textos del sur de Aragón y de Cataluña de finales del siglo xir y principios del xiII. Junto a una delimitación de los términos y la concesión de diversas franquicias a quienes fuesen a poblar, Blasco de Alagón concedía la villa a quinientos pobladores para que habitasen con el fuero de Sepúlveda y de Extremadura ${ }^{36}$.

Esta será la única vez que, entre las más de trescientas cartas pueblas medievales valencianas, se poblase un lugar con dicho fuero. Por ello esta excepcionalidad ha llamado la atención de los investigadores desde antiguo, y no ha dejado de haber diversas interpretaciones que han sido recogidas y bien resumidas en los citados trabajos de $\mathrm{V}$. García Edo sobre Morella. Lo cierto es que en los años siguientes el citado Blasco de Alagón fue poblando diversas aldeas del término general del castillo y villa de Morella, caso de Vallibona en noviembre de $1233^{37}$, y de Fredes y El Boixar el 15 de marzo de 1236, según el fuero otorgado a Morella ${ }^{38}$. Pero este ya no era, según dicho noble, el citado de Sepúlveda sino el fuero de Zaragoza: ad bonos foros et usus et consuetudines Cesaranguste, sicut populatores de Morella sunt populati. Vicent García Edo, en el artículo citado, da una argumentación para dicho cambio que, sin tener prueba documental, es una hipótesis francamente razonable. En el contexto de la rendición de Morella, Blasco de Alagón dio un primer fuero en el marco de lo absolutamente usual en la región vecina de Teruel hasta ese momento: un modelo de villa y aldeas con concejo de frontera y para atraer caballeros y peones que contribuyesen a la defensa militar. Pero dicho modelo daba amplias competencias al nuevo concejo para repoblar el término general, actual comarca de Els Ports de Morella, tal como haría el concejo de Teruel en esos ańos y siguientes. Por ello, los repartimientos de heredades o fundación de aldeas por Blasco de Alagón entre 1233 y 1239 adoptarían todos la concesión del fuero de Zaragoza a nivel local y, de facto, dicho noble convertiría también a Morella a dicho fuero a fin de reforzar su poder señorial.

En cuanto al fuero de Teruel para el castillo y villa de Jérica, también tiene un contexto peculiar y aislado. Hay que tener en cuenta primero la fecha, el año 1238, antes de la conquista de la ciudad de Valencia y de la creación del nuevo reino de Valencia. Y en

36 ARV, Real Cancillería, registro 698, f. 226r-v. Publica: Guinot Rodríguez, Cartes de poblament medievals valencianes, pp. 89-91; GARCía EDo, Vicent. «La carta de poblament de 1233 i el fur general de Morella». Papers dels Ports de Morella, 2002, vol. 1, pp. 92-94; ÍDEm. «La Carta Puebla de 1233 y el Fuero General de Morella». En El fuero de Laredo en el octavo centenario de su concesión. Santander: Universidad de Cantabria, 2001, pp. 587-605.

37 Vallibona: Documento perdido actualmente. Publica: Guinot Rodríguez, Cartes de poblament medievals valencianes, pp. 99-100.

38 Fredes y El Boixar: AHN, Clero, Benifassà, pergaminos, carpeta n. ${ }^{\circ}$ 420, n. ${ }^{\circ}$ 3. Publica: Guinot Rodríguez, Cartes de poblament medievals valencianes, pp. 113-114. 
DE LOS FUEROS LOCALES AL FUERO DE VALENCIA EN EL MARCO DEL PROCESO DE INSTAURACIÓN DE LA SOCIEDAD FEUDAL DEL SIGLO XIII EN EL REINO DE VALENCIA

ese momento, tal como explicamos en nuestro libro Els limits del Regne, el territorio del concejo de Teruel, en base a su fuero de 1177, llegaba hasta este término de Jérica. Ello llevaría a un conflicto judicial en 1271, a raíz de la delimitación del reino de Valencia incluida en la modificación del preámbulo del Fuero de Valencia de ese año, y la resolución por parte del tribunal real de que Jérica y su distrito quedaban en el reino valenciano mientras las villas vecinas de Manzanera, Rubielos de Mora, etc., quedaban en Teruel ${ }^{39}$. Por tanto, en 1238 es comprensible que el rey Jaime I considerase que Jérica quedaba dentro de los términos generales de Teruel y por ello dicha concesión.

Igualmente individual y aislada es la concesión del fuero de Daroca al castillo de Villamalefa en 1242. Dicho término formaba parte del distrito de Arenoso, que había pasado de territorio musulmán a señorío feudal por una vía bien peculiar: su privatización por parte del sayyid Abu Saïd, el último gobernador almohade de Valencia y convertido en señor feudal a partir de su alianza con Jaime I en el momento de la conquista de Valencia, tal como estudiaron M. ${ }^{a}$ Carmen Barceló y Robert I. Burns ${ }^{40}$. A partir de la toma de la capital valenciana, dicho Abu Saïd fue poblando con cristianos algunos lugares de ese señorío, pero sólo en el primer caso hizo uso de ese fuero. En cuanto a por qué ese en concreto, hay indicios documentales de relaciones de dicho Abu Saïd con ese concejo y podría deberse simplemente al conocimiento de este texto.

Finalmente el caso del fuero de Fontana para la alquería de Benimahomet, de hecho el origen físico de la futura fundación de la villa de Castellón de la Plana a partir de 1251, también es casi coetáneo a la conquista de la ciudad de Valencia y promulgación de su Costum, pues es de marzo de 1239. Y el otorgante, el conde Nuño Sanz del Rosellón, también aparece como única vez en que dirigió una repoblación en Valencia ${ }^{41}$. Hasta ahora nadie ha conseguido identificar dicho fuero de Fontana; quizá habría que pensar en el Rosellón o entorno geográfico, pues algunas de las cláusulas de rentas y derechos que se exigen no son los usuales en el marco valenciano de aquellos años, pero en todo caso es también un caso peculiar y que no tuvo continuidad, incluso ni legalmente, ya que la posterior fundación real de Castellón no se basó en ese fuero.

\subsection{Los fueros mayoritarios: Costum de Lleida, fueros de Zaragoza y de Valencia}

En cuanto a los otros tres fueros o costumbres usados de forma más amplia, Lérida, Zaragoza y Valencia, el minoritario es el primero de ellos y la verdad es que también remite a un contexto de dos señores concretos. La Costum de Lleida tan solo fue utilizada por la orden de San Juan del Hospital para su seńorío del castillo de Cervera del Maestrat,

39 Guinot Rodríguez, Els limits del Regne.

40 Barceló Torres, M. ${ }^{a}$ Carmen. «El Sayyid Abú Zayd: príncipe musulmán, señor cristiano». Awraq, 1980, vol. 3, pp. 101-109; BuRns, Robert I. «Príncipe almohade y converso mudéjar: nueva documentación sobre Abu Zayd». Sharq al-Andalus, 1987, vol. 4, pp. 109-122; ÍDEM. «Daughter of Abu Zayd, last Almohad ruler of Valencia: the family and Christian seigniory of Alda Ferrandis, 1236-1300». Viator, 1993, vol. 24, pp. 143-187.

41 Guichard, Pierre y SÁnchez Adell, José. «La carta puebla de Benimahomet y el poblamiento de Castellón en el siglo XIII». Boletín de la Sociedad Castellonense de Cultura, 1984, vol. LX, pp. 352-370. 
para cuatro localidades (término de Cervera, Sant Mateu, Rossell y Carrascal) y entre los años 1233 y 1239, si bien también debió ser concedida a los otros lugares de dicho término general: Traiguera, Canet y La Jana. Pero, una vez promulgado el Costum de Valencia en 1239/40, dicha orden militar pasó a otorgar este nuevo fuero a sus nuevos señoríos de Torrente y Silla (situados dentro de los límites del término general de la ciudad), pero también a Sueca y alquerías vecinas, en término general de Cullera y bajo condominio entonces con la corona. En cuanto a los otros seńoríos hospitalarios del reino de Valencia del siglo XIII, tuvieron o bien el fuero de Zaragoza o bien el de Valencia, pero lo cierto es que no fueron concedidos por la orden, sino que procedían de repoblaciones anteriores, bien de la corona bien de algún noble (Onda, Vilafamés, Vall de Perputxent), o eran pequeños lugares situados dentro del término de una villa que ya tenía un fuero anterior (Binaraix en Borriana, y la Vall d'Alba en Vilafamés) ${ }^{42}$.

El otro poder señorial que utilizó el Costum de Lleida fue el obispo de Tortosa, Ponç de Torrella, para la villa de Cabanes y el lugar de Bell.lloc del Pla, que conformaban una misma unidad señorial en la región al norte de Castellón. Las fechas son 1243 y 1250, respectivamente, posteriores, por tanto, a la promulgación del Costum de Valencia y ajenas a la posible política real de extensión del texto valenciano. Asimismo es llamativo que, siendo obispo de Tortosa, no otorgue el costum de dicha ciudad sino el de Lérida, lo que probablemente apunta al grado de evolución jurídico-política de una y otra costumbre en esa década de 1240 .

En todo caso los dos códigos mayoritarios fueron el fuero de Zaragoza y la costum de Valencia, llamados posteriormente Fuero de Aragón y Fuero de Valencia, si bien dicho cambio no se produjo simultáneamente. Si en el primer caso hay que remontarse a la década de 1270, en cambio el uso de la expresión Fuero de Valencia fue muy temprana, ya por nobles y particulares en la década de 1240 , y por la corona a partir de la de $1250^{43}$.

\subsubsection{El fuero de Zaragoza}

Tal como hemos explicado más arriba, el más antiguo es el zaragozano, aplicado de forma mayoritaria por nobles aragoneses en las comarcas de Castellón, pero también por el propio monarca Jaime I, o sus lugartenientes, en alguna villa real: Borriana (1233), y Vilafamés y Vinaròs (1241). En realidad su uso por la monarquía fue muy limitado y ello en un contexto histórico concreto, cosa que se ha diluido al generalizarse la idea de la difusión amplia del fuero de Aragón desde finales del siglo xiII. Pero de nuevo hemos de tener en cuenta las fechas y los casos: la corona tan solo lo concedió en estas tres ocasiones como novedad, pues el caso de Vila-real en 1274 se debe a que fue fundada por la corona dentro de los límites del término de la villa de Borriana, aunque fuese segregada en aquel momento por el monarca. Y en cuanto a las de Vilafamés y Vinaròs, aunque son posteriores a la promulgación de la Costum de Valencia, lo cierto es que son muy

42 Guinot Rodríguez, Enric. «La Orden de San Juan del Hospital en la Valencia medieval». Aragón en la Edad Media, 1999, vol. 14-15, pp. 721-742.

43 García Edo, «Origen i expansió dels Furs o Costum de València», pp. 175-200. 
DE LOS FUEROS LOCALES AL FUERO DE VALENCIA EN EL MARCO DEL PROCESO DE INSTAURACIÓN DE LA SOCIEDAD FEUDAL DEL SIGLO XIII EN EL REINO DE VALENCIA ENRIC GUINOT RODRÍGUEZ

inmediatas y que en 1245 Jaime I ya otorgó dicha costum a la villa de Denia y a partir de ahí de forma sistemática. En nuestra opinión, que únicamente existan dichas dos concesiones en Vilafamés y Vinaròs, y por parte de oficiales reales, tendría más que ver con el cambio de concepto político para el nuevo reino de Valencia por parte de la corona a partir del reinicio de la guerra de conquista en 1244 sobre Xátiva y Dénia, que no con un supuesto caos organizativo o contradictorio, como en alguna ocasión se ha planteado. De hecho, este cambio de visión ya fue apuntado por V. García Edo en su momento para dichos ańos de 1241 a 1244, ligado al inicio del uso de la expresión «Fuero de Valencia».

En cuanto al fuero de Zaragoza, según los listados de M. Gual, E. Guinot, A. García Sanz, V. García Edo, G. Navarro y V. Baydal, entre otros, fue el concedido, entre 1233 en Borriana y 1316 en Vilar de Canes, en un total de treinta ocasiones. Pero debemos hacer algunas matizaciones: hay más de una concesión a la misma localidad (Borriana y Albocásser están dos veces). También hay concesiones a alquerías o pequeños lugares dentro del término de una villa, por lo que reciben el de ella, más antiguo y con jerarquía sobre el conjunto del territorio: caso de las alquerías de Seca (orden del Temple) y Binaraix (orden del Hospital) en término de Borriana. Y sobre todo tenemos las concedidas dentro de los términos generales de Morella, Les Coves de Vinromà y Culla por Blasco de Alagón entre 1233 y 1239: Vallibona, Boixar y Fredes, Mola Escaboça, Vilanova del Castell de Cabres, Coratxar, Salzadella, Benassal, Catí, Albocàsser, Castell de Cabres y Vilafranca. De hecho, a la muerte de Blasco de Alagón en 1240, los nuevos señores de Les Coves y Culla, orden de Calatrava y Guillem de Anglesola, continuaron dando dicho fuero a los nuevos lugares poblados dentro de sus términos: Albocàsser y Vilanova d'Alcolea en el primer caso, y Culla, Vistabella y Atzeneta en el segundo, además de algún otro pequeño caballero dentro de su término (Joan de Brusca en Tírig, término general de Les Coves).

Hasta ahora todos los trabajos publicados han hecho incidencia en la cantidad de lugares poblados a fuero de Zaragoza/Aragón frente a fuero de Valencia, pero en nuestra opinión es más relevante para valorar su incidencia el comprobar cuándo fue otorgado a la villa centro de distrito castral y seńorío, y en cuántos de ellos distintos, pues, como hemos observado más arriba, todo nuevo lugar o aldea fundado o repoblado dentro del término de una villa o unidad señorial debía recibir el mismo fuero del núcleo central. Por ello, aunque en el término general de Morella Blasco de Alagón y alguno de sus sucesores dieron fuero de Zaragoza a diversos lugares en la década de 1230, todos ellos tuvieron que remitirse al fuero que tenía la villa de Morella. De hecho, al no haberse conservado todas las cartas pueblas, hay alguna dificultad en darse cuenta de ello. Por ejemplo, no conocemos el texto original de Les Coves de Vinromà, tan solo su confirmación por Artal de Alagón en 1281, pero dado que tanto Blasco de Alagón en Albocàsser y la orden de Calatrava en Vilanova d'Alcolea otorgan el fuero zaragozano, la única razón posible es que el texto original de Les Coves, probablemente del propio Blasco de Alagón y hoy perdido, estuviese a dicho fuero de Zaragoza.

En resumen, que este fuero fue concedido entre 1233 y 1272 en los términos generales de Morella y en los distritos señoriales de Culla, Les Coves de Vinromà, Ares y, con un único caso, en la tenencia de Alcalatén (Xodos, 1254). A ellos cabe añadir los lugares reales de Benicarló y Vinaròs, el término de Vilafamés y el lugar de Almassora (señorío 
del monasterio de Santa Cristina de Somport unos pocos años y también antes de la conquista de la ciudad de Valencia, 1237).

Y si nos fijamos en sus otorgantes, el «gran» responsable es el noble Blasco de Alagón, señor de Morella, Les Coves de Vinromà y Culla, y sus términos, entre 1232 y 1239, pues sus sucesores en dichos señoríos continúan con dicha concesión del fuero de Zaragoza en sus distritos respectivos como era preceptivo. A ellos tan solo cabe ańadir el linaje de Eximén de Urrea, señor de Alcalatén, y don Ladrón, señor de Ares del Maestrat, además del caso de Almassora, señorío del obispado de Tortosa, herederos de la carta puebla antes citada del monasterio de Somport. Porque Jaime I, en los años siguientes, cambió a fuero de Valencia los lugares de Benicarló y Vinaròs, así como el castillo de Vilafamés. En total cinco diferentes unidades señoriales y una villa real, Borriana, doblada con la fundación de Vila-real en 1274.

Llegados a este punto creemos que es relevante el fijarnos también sobre cuándo se produce el cambio de uso del término fuero de Zaragoza a fuero de Aragón. Según los listados de M. Gual, E. Guinot, A. García Sanz, V. García Edo, G. Navarro y V. Baydal, entre otros, el fuero de Zaragoza fue el concedido entre 1233 en Borriana y 1316 en Vilar de Canes en treinta ocasiones. Pero hay que tener en cuenta que la citada de Vilar de Canes de 1316 sigue el fuero del término general de Culla, donde se encontraba el lugar, mientras que la de Xodos, datada tradicionalmente en 1292 (también por nosotros en la colección de cartas pueblas valencianas), en realidad es de 1254, tal como demostró en su momento César Mateu ${ }^{44}$.

Ello quiere decir que la última vez que se usó el fuero de Zaragoza lo fue en 1272 por Guillem d'Anglesola, señor de la tenencia de Culla, para la puebla de Atzeneta del Maestrat. Y la primera concesión del fuero de Aragón es la fundación de Jaime I de Vilareal en 1274, en la que sigue el fuero de Zaragoza de la villa de Borriana, de donde es segregada la nueva puebla ${ }^{45}$. Después hay un buen salto cronológico para llegar a la de Andilla en 1292 por parte de Eximén Pérez de Arenós y la de Chiva en 1303 por parte de Bernat Guillem d'Entença, siguiendo luego una quincena más durante el resto del siglo XIV si bien bastante concentradas en algún señorío concreto como el condado de Jérica y la baronía de Chelva.

Evidentemente nos preguntamos por qué el rey Jaime I decidió usar la expresión fuero de Aragón en el reino de Valencia por primera vez en una carta puebla en dicho año de 1274, y más cuando su nuevo uso tardó dieciocho años más. Sería posible que tuviese

44 Mateu Beltrán, César. La carta de poblament de Xodos: documentació, història i usos socials del català al País Valencià des de l'Edat Mitjana fins al segle XX. Trabajo final de carrera. Edición electrónica: Barcelona: Universitat Oberta de Catalunya, 2011.

45 Volumus et concedimus vobis dictis populatoribus et vestris imperpetuum quod sitis populati in dicta populacione ad forum Aragonum et ad illam franquitatem ad quod dicti homines Burriane sunt populati, et in carta quam inde a nobis habent plenius continetur. Et nos, de presenti, ipsum forum et franquitatem, sicut ipsi homines Burriane habent, vobis et vestris concedimus atque donamus. Pueden verse las consideraciones sobre el tema por parte de García SAnZ, Arcadi y García EDo, Vicent. La carta pobla de Vila-real (20 de febrer de 1274). Vila-Real: Ajuntament de Vila-Real, 1995; García Edo, Vicent. "Adopció del fur de València per la vila de Vila-Real a les Corts Generals del Regne de 1329-1330». En Miscelánea homenaje a J. M. Doñate. Vila-Real: Ajuntament de Vila-Real, 1993, pp. 195-215. 
DE LOS FUEROS LOCALES AL FUERO DE VALENCIA EN EL MARCO DEL PROCESO DE INSTAURACIÓN DE LA SOCIEDAD FEUDAL DEL SIGLO XIII EN EL REINO DE VALENCIA

que ver con los cambios en el Fuero de Valencia de las cortes de 1271 y con los conflictos por la delimitación de fronteras entre Valencia y Aragón de los dos años siguientes. Y con ello las crecientes reclamaciones de la nobleza aragonesa, en el marco de la Unión, a través de sus instituciones, cortes o Justicia de Aragón, en defensa de ese fuero territorial en el nuevo reino valenciano ${ }^{46}$.

En cuanto a su uso a partir de la puebla de Andilla en 1292, parece más lógico y normal dado todo lo sucedido en el reinado de Pedro III el Grande, con la revuelta nobiliaria de la Unión aragonesa y sus reclamaciones forales y políticas sobre el reino de Valencia, tal como ha estudiado recientemente V. Baydal. Por ello, en nuestra opinión, ello corresponde ya a otro periodo histórico y no al que tenemos aquí entre manos sobre el paso de los fueros locales a un fuero territorial de carácter regnícola durante las décadas centrales del siglo XIII.

\subsubsection{El fuero de Valencia}

Finalmente, y en cuanto al costum y fuero de Valencia, los trabajos sobre sus orígenes, elaboración, promulgación y territorialización son sin duda más completos actualmente y nos permiten sintetizar de forma más rápida. Primera cuestión: tal como hemos explicado más arriba, el proceso de conquista y repoblación de las tierras valencianas se desarrolló entre 1232 y septiembre de 1238, momento de conquista de la ciudad de Valencia, en base a la concesión de diversos fueros habituales en Aragón y Cataluña en esos años. Es a raíz de la ocupación y repartimiento de la ciudad de Valencia cuando el rey Jaime I promulgaría un código judicial de carácter local llamado costum de Valencia y con un planteamiento de aplicación a su territorio urbano, por tanto similar a las costumbres de Tortosa y Lérida pero también a fueros como los de Teruel, Daroca o Albarracín.

Aunque tradicionalmente se había datado dicha promulgación real entre 1239 y 1240, según los últimos trabajos de V. García Edo, basados en la presencia en la ciudad de los testigos citados en el preámbulo, debería situarse su publicación en los tres meses finales de 1238. Según A. García Sanz, su autor sería Pere Albert, canónigo de la catedral de Barcelona, jurista de reconocido prestigio en aquel momento y responsable también de una recopilación de los Usatges de Cataluña. Y esta Costum urbana se basó en buena medida en la recepción del llamado «Derecho Común» y más concretamente en la estructura y partes significativas de las rúbricas del código de Justiniano, pero también en bastantes partes procedentes del Costum de Lleida ${ }^{47}$.

Dejando aparte las cuestiones jurídicas sobre el texto, lo que ahora nos parece más relevante es cómo se dio el proceso de difusión de dicha costum/fuero de Valencia. Pues

46 González Antón, Luis. Las Uniones aragonesas y las Cortes del reino. Madrid: Conejo Superior de Investigaciones Científicas, 1975; BAYDAL, Els valencians, des de quan són valencians?; GARCía Edo, "Aragón contra Valencia: la disputa foral», pp. 65-102; García Edo, "El Privilegium Magnum del rey Pedro I», pp. 10-62.

47 García Edo, «El parentesco entre las costumbres de Lérida (1228), Valencia (1238) y Tortosa (1273)», pp. 173-188; García SAnZ, Arcadi. "El jurista Pere Albert i la seva obra». En Estudis històrics $i$ documents dels arxius de protocols del Col.legi de Notaris de Barcelona, 1996, pp. 7-38. 
ello se produjo en dos etapas: una primera, comprendiendo buena parte del reinado de Jaime I, hasta la década de 1260, en que se extendió de forma individual, localidad a localidad, concedida bien por el monarca bien por el señor respectivo, sin que en ningún momento en los primeros años se promulgase como una ley territorial. En nuestra opinión esto tan solo se dio a partir de dicha década de 1260 y más en concreto a partir de las cortes de Valencia de 1261, donde se modificaron fueros, se añadieron otros, se tradujeron del latín y se planteó su carácter de ley para el nuevo reino con una delimitación de sus fronteras ${ }^{48}$.

Creemos que es bastante clarificador repasar el listado de concesión del costum/fuero de Valencia en cartas pueblas del siglo xiII. Su ámbito cronológico va de la concesión en 1241 por la orden de Santiago al lugar de Museros, en la Huerta de Valencia, hasta la de Vilajoiosa en 1300 por el noble Bernat de Sarrià, con un total de 53 poblaciones diferentes, repartidas por todo el reino, desde Peníscola al norte hasta Biar y Vilajoiosa al sur. Los concedentes son muy diversos: hay un claro protagonismo de la corona, tanto de Jaime I como de Pedro III, pero también de Alfonso III y Jaime II, lo que nos indica la continuidad en el tiempo de la voluntad real de generalizar el fuero de Valencia una vez promulgado. Y también es concedido por órdenes militares, la catedral de Valencia, monasterios y nobleza de linaje aragonés, navarro y catalán.

Hay además algunos detalles interesantes: las primeras concesiones, entre 1241 y 1245, año del final de la conquista, son en todos los casos, menos en uno, de lugares situados dentro del término general de Valencia, por tanto dentro de su jurisdicción. La excepción es el castillo de Vilafamés, de realengo. Y los otorgantes son tanto órdenes militares (Santiago, Hospital) como la catedral de Valencia o nobles laicos, uno catalán (Bernat Vidal) y otro aragonés (Asalito de Gúdal). Posteriormente, en las décadas siguientes, todas las concesiones de fuero dentro de dicho término general de la ciudad de Valencia fueron también de este fuero, y de nuevo con protagonismo de nobles de origen aragonés o no: Alcàsser (1248) por Artal de Foces, Almussafes (1251) por doña Navarra de Ahuero y Sancho López de Sentia en 1281.

Pero lo relevante es que en otros lugares de repoblación cristiana, en señoríos de nobles de linaje aragonés o navarro, también concedieron el fuero de Valencia en dicho siglo XIII. Es el caso de Pedro de Montagut, quien pobló Carlet en 1252 con este fuero de Valencia; de doña Berenguela Fernández y su hijo Pedro Fernández de Híjar, hijo de Jaime I, señores de Buñol, quienes lo conceden en 1260 al lugar de Sieteaguas. De Eximén de Urrea en 1277 para el lugar de Sollana; de dońa Teresa Gil de Vidaure y el también hijo de Jaime I, Jaime de Jérica, para el castillo de Planes y el lugar de Almudaina; de Artal de Alagón para Les Coves de Vinromà en 1281; y de Gonzalo García para Moixent en 1303. A ellos cabría añadir la orden de Calatrava, radicada en Alcañiz, que dió el fuero de Valencia a Begís en 1276, y del monasterio oscense de Roda al lugar de Alhorre, término de Morella, en $1254^{49}$.

48 Peset Reig, «Furs de Valencia: su sentido y vigencia», pp. 361-378; López Elum, Los orígenes de los Furs de València y de las Cortes en el siglo XIII, capítulos II y III; BAYDAL, Els valencians, des de quán són valencians?, pp. 29-110.

49 En el caso de la orden de Calatrava también dió el fuero de Valencia a Massamagrell en 1271 y a Massanassa en 1278, pero ambos lugares estaban dentro del término general de Valencia y seguirían por ello 
DE LOS FUEROS LOCALES AL FUERO DE VALENCIA EN EL MARCO DEL PROCESO DE INSTAURACIÓN DE LA SOCIEDAD FEUDAL DEL SIGLO XIII EN EL REINO DE VALENCIA ENRIC GUINOT RODRÍGUEZ

Asimismo, debemos tener en cuenta dos consideraciones más. La primera es que, en realidad, el fuero de Valencia, ni ningún otro, nunca se otorgó de forma individual a las abundantes poblaciones de mudéjares, allí donde continuó o se substituyó según los casos la población andalusí anterior, y para el siglo XIII estamos hablando de al menos la mitad de la población y el territorio valenciano. En dichos lugares siguió vigente la ley islámica, la Sunna e Xara, si bien como derecho complementario, al menos a partir de finales del siglo XIII o principios del XIV, podemos considerar que también se extendió por parte de la corona el fuero de Valencia.

La segunda es que, a partir de la década de 1270, parte de la nobleza con patrimonio en el reino de Valencia, en general la de linaje de origen aragonés o porque eran linajes con patrimonio en los dos reinos, pero también algunos nobles catalanes o de origen catalán e incluso navarro, reclamó la aplicación del fuero de Aragón en sus señoríos. Pero en realidad dicha reclamación no coincide con la concesión de fuero de Aragón en nuevas pueblas, aparte el caso de Vila-real ya explicado, pues estas solo empiezan en 1292 con Andilla, Chiva en 1303, Sinarcas en 1305 y siguen así en el siglo XIV, siempre por parte de nobles de linaje aragonés. Hay, por tanto, un intervalo cronológico entre la reclamación individual del linaje nobiliario de su estatuto personal para ser situados bajo el fuero de Aragón, y la aplicación de dicho fuero a las poblaciones de su señorío. Un intervalo de al menos una generación, entre la década de 1270 y la de 1290 , lo que implica que no podemos confundir ambas realidades.

4 LA CONFLICTIVA REACCIÓN DE LA NOBLEZA A LA TERRITORIALIZACIÓN DE UN FUERO regnícola: el Fuero de Aragón frente al Fuero de Valencia (1261-1329/30)

Creemos que el planteamiento que hemos desarrollado hasta ahora pone en evidencia la lógica local en cuanto a la concesión de los diversos fueros en el nuevo reino de Valencia a partir del inicio de su conquista. Cómo la difusión del fuero de Zaragoza tiene también una lógica propia en cuanto a su concesión antes de la promulgación del de Valencia, y su ampliación únicamente en el marco de los mismos señoríos y alguna villa real donde fue dado antes de 1239 . Y cómo existe un decalage cronológico respecto a las primeras concesiones del fuero de Aragón en la década de 1290.

Y si la primera vía de concesión del Fuero de Valencia fue la de la carta puebla local, lo cierto es que la territorialización del fuero de Valencia se produjo de facto por otra vía paralela, primero de forma indirecta y a partir de las cortes de Valencia de 1261 de forma ya más consciente. Indirecta porque los sucesivos privilegios de la corona a la ciudad de Valencia desde 1239 en adelante fueron también aplicados con carácter general para todo el reino, generalmente porque así lo indicaba el texto. Por ejemplo, uno de los primeros, en 1240, regulaba la función de fedatarios de los notarios y se indicaba que ello tendría valor para todo el reino, y así sucesivamente.

dicha jurisdicción urbana. En cuanto al monasterio de Roda y Alhorre, la fecha de 1254 es posterior al cambio de fuero de Morella. 
Según A. García Sanz, V. García Edo, M. Peset, P. López Elum y otros estudiosos de las cortes y la génesis foral valenciana, en enero de 1250 Jaime I incorporó parte de dichos privilegios al texto foral, lo que reforzaba su aplicación general. Pero sobre todo fue en lo que se han considerado las primeras cortes valencianas en el año 1261 cuando se produjo una ampliación, revisión y traducción de la primitiva Costum, redactada en latín. Todo indica que es en ese momento cuando se plantea su carácter de fuero territorial para el reino de Valencia, y de ahí la posterior y progresiva resistencia de parte de la nobleza radicada en el nuevo reino, de linajes aragoneses, a aceptar quedar sometidos al fuero valenciano. Posteriormente, en las cortes valencianas de 1271 se ratificaría dicho planteamiento de aplicación general del fuero de Valencia a todo el reino, y lo mismo en las cortes de 1283 ya con Pedro III. Se trata de una cuestión tratada anteriormente por muy diversos autores, no solo valencianos sino también aragoneses, caso del amplísimo estudio de Luis González Antón sobre las Uniones aragonesas en el cual también le dedica su espacio a esta cuestión, y en general todos ellos siguen el relato de los hechos aportado por el cronista Jerónimo Zurita.

Es, pues, en este contexto posterior en el que se fue construyendo la verdadera oposición fuero de Aragón/fuero de Valencia, cuando el primer patriciado urbano de la ciudad de Valencia, a través de las primeras cortes, defiende la generalización del fuero, y por tanto de los privilegios incluidos en ellos en 1261 y 1271, unos privilegios que evidentemente benefician a dicho grupo ciudadano. Ante ello, la reacción nobiliaria en defensa de la total autonomía de sus señoríos, no solo frente al poder real y sus oficiales, sino también frente a los privilegios ciudadanos sobre el conjunto del reino. Y al ser nobles aragoneses o de origen aragonés del linaje, es razonable entender que se envolviesen en su condición jurídica de nobleza aragonesa usando los instrumentos institucionales que estaban creando en dicho reino.

\section{Conclusiones}

El trabajo que presentamos ha pretendido aportar un poco más de luz al proceso de transición de fueros locales a un fuero territorial o para todo un reino, proceso que en la corona de Aragón se produjo en las décadas centrales del siglo XIII, coincidiendo con el proceso de repoblación y construcción de la sociedad feudal en las tierras de Mallorca y, sobre todo, Valencia. Así, en el marco de una generación, los reinos de dicha Corona empezaron la transición hacia la territorialización de un fuero propio para cada uno de ellos.

Para entender cómo se llegó a dicho proceso hemos revisado cómo se concedían fueros locales tanto por la monarquía como por la nobleza en Aragón y Cataluña a finales del siglo XII y principios del xIII. Hemos constatado su diversidad, aunque se diese el predominio del fuero de Zaragoza en Aragón, y de la primera Costum de Tortosa en el sur de Cataluńa. Es así como entendemos que la primera etapa de la repoblación de Valencia, entre 1232 y 1239, estuvo marcada exactamente por el mismo modelo de comportamiento. Cada señor otorgó a los lugares que se repoblaron el fuero de su región de origen, más allá de dónde fuesen provenientes los repobladores reales de cada lugar. Era el 
DE LOS FUEROS LOCALES AL FUERO DE VALENCIA EN EL MARCO DEL PROCESO DE INSTAURACIÓN DE LA SOCIEDAD FEUDAL DEL SIGLO XIII EN EL REINO DE VALENCIA

poder feudal quien marcaba la ley y eso es lo que hizo el rey Jaime I con la concesión de la Costum a la ciudad de Valencia en el momento de su conquista, repartimiento e inicio de la repoblación, a finales de 1238 o inicios de 1239, siendo su radio de aplicación el término general de la ciudad, tal como se comprueba en los fueros dados a los lugares situados dentro de él.

En el conjunto del reino valenciano fundado por Jaime fueron utilizados siete fueros diferentes a lo largo del siglo XIII, si bien cuatro de ellos fueron prácticamente de caso único y siempre antes del final de la conquista en 1245. También tuvo un carácter limitado el uso de la costum de Lleida, por lo que fueron el fuero de Zaragoza y la costum/ fuero de Valencia los que se generalizaron. Pero con una importante diferencia: hemos argumentado documentalmente cómo el zaragozano tan solo se extendió en las décadas siguientes en lugares situados dentro de señoríos o términos de villas que lo habían recibido antes de 1239, fecha de la promulgación del de Valencia. Con esto matizamos la idea generalmente difundida de que el fuero de Zaragoza tuvo posibilidad de extenderse según la libre disposición de la nobleza durante el resto del siglo XIII y, de hecho, el último caso documentado es el de la fundación de Atzeneta en 1272. Aparte el caso peculiar de Vila-real en 1274, a partir de ahí se produjo un intervalo hasta 1292 para encontrar la primera concesión del fuero de Aragón a Andilla, lo que implica que el mecanismo de aplicación de un fuero a una localidad, fuese el de Valencia o fuese el de Aragón, era el que existiese una carta puebla que lo indicase. Al mismo tiempo es igualmente relevante el recordar que cerca de la mitad del territorio valenciano continuó poblado de mudéjares al menos hasta principios del siglo XIV, por lo que en dichos lugares no se introdujo localmente ningún fuero de la sociedad cristiana.

En este contexto es en el que la monarquía, en paralelo, de forma aparentemente limitada en 1251 y ya de forma clara, amplia y general en 1261, introdujo privilegios que abarcaban a todo el reino en el texto de los fueros de Valencia, y ello se produjo en el marco de lo que se consideran las primeras cortes valencianas con presencia de villas reales y de nobles. Este sería pues el momento de cambio político en el que estalló el auténtico conflicto de intereses entre la mayor parte de la nobleza radicada en Valencia, ampliamente de linajes aragoneses, frente a los objetivos también políticos de la primera generación de ciudadanos de la capital. Un proceso que se agravó con las nuevas reformas de los fueros en las cortes de 1271 y aún más con los nuevos privilegios y leyes de las cortes del otoño de 1283, ya en tiempos de Pedro el Grande. Pero conflictos más de poder político, y también económico, que no de competencias «nacionales», al menos en este periodo que estamos analizando.

\section{REFERENCIAS BIBLIOGRÁFICAS}

Barceló Torres, M.a Carmen. «El Sayyid Abú Zayd: príncipe musulmán, señor cristiano». Awraq, 1980, vol. 3, pp. 101-109.

Barrero Sanz, Ana M.a. «El derecho Romano en los Furs de Valencia de Jaime I». Anuario de Historia del Derecho Español, 1971, vol. 41, pp. 639-664, y en $1 r$ Congreso de Historia del País Valenciano. Valencia: 1971, t. 2, pp. 471-478. 
Barrero Sanz, Ana M.a. "Los fueros de Teruel y Albarracín (apunte historiográfico)». En Los Fueros de Teruel y Albarracín. Teruel: Instituto de Estudios Turolenses, 2000, pp. 269-279.

BAYDAL, Vicent. Els valencians, des de quan són valencians? Barcelona-Catarroja: Editorial Afers, 2016.

Belenguer Cebrià, Ernest. «En torno a la sugestiva tesis de Joan Reglà: el dualismo valenciano y sus desequilibrios». Boletín de la Real Academia de la Historia, 1977, vol. CLXXIV, pp. 141-171.

Beneyto Pérez, Juan. «Sobre la territorialización del código de Valencia». Boletín de la Sociedad Castellonense de Cultura, 1934, vol. XII, pp. 187-197.

Burns, Robert I. "Daughter of Abu Zayd, last Almohad ruler of Valencia: the family and Christian seigniory of Alda Ferrandis, 1236-1300». Viator, 1993, vol. 24, pp. 143-187.

Burns, Robert I. «Príncipe almohade y converso mudéjar: nueva documentación sobre Abu Zayd». Sharq al-Andalus, 1987, vol. 4, pp. 109-122.

Cabanes Pecourt, M. a Desamparados. «Aspectos demográficos de la conquista: población preexistente y repoblación en la ciudad de Valencia». En En torno al 750 aniversario. Valencia: Generalitat Valenciana, 1989, t. 1, pp. 303-318.

Cabanes Pecourt, M. a Desamparados. «El barrio de Zaragoza y los zaragozanos en la repoblación valenciana». Aragón en la Edad Media, 2011, vol. 22, pp. 49-66.

Cabanes Pecourt, M. a Desamparados. «Tarazona en la repoblación valenciana de 1239». Aragón en la Edad Media, 1987, vol. 7, pp. 39-46.

Cebrián Ibor, Santiago. "Los fueros de Valencia». En III Congreso de Historia de la Corona de Aragón. Valencia: Ajuntament de Valencia, 1923, t. 1, pp. 605-665.

Chaвás, Roque. Génesis del derecho foral de Valencia. Valencia: Imprenta de F. Vives Mora, 1902, reeditado en Chabás, Roque. Opúsculos. Valencia: Consell Valencià de Cultura, 1995.

Colón, Germà y ABAD, Isabel. Furs de València. Vols. 10 y 11. Barcelona: Editorial Barcino, 2007.

Colón, Germà y García Edo, Vicente. Furs de València. Vol. 9, Barcelona: Editorial Barcino, 2002.

Colón, Germà y García SAnz, Arcadi. Furs de València. 8 vols. Barcelona: Editorial Barcino, 1970-1998.

Corral Lafuente, José L. «El impacto social de los fueros de la Extremadura aragonesa». En Los Fueros de Teruel y Albarracín. Teruel: Instituto de Estudios Turolenses, 2000, pp. 19-30.

Delgado Echeverría, Jesús. Los Fueros de Aragón. Zaragoza: Caja de Ahorros de la Inmaculada, 1997.

Dualde Serrano, Manuel. Fori Antiqui Valentiae. Edición crítica. Madrid-Valencia: Consejo Superior de Investigaciones Científicas, 1950-1967.

Estal, Juan Manuel del. Documentos inéditos de Alfonso X el Sabio y del Infante, su hijo, don Sancho. Alicante, 1984.

Estal, Juan Manuel del. Libro de los primitivos privilegios de Alfonso X el Sabio a Alicante. Estudio histórico-critico y ed. facsímil. Madrid: EDILAN, 1984.

Ferrer Navarro, Ramón. "El fuero de Aragón y la pretendida dualidad valenciana». Aragón en la Edad Media, 1989, vol. VIII, pp. 257-270.

Font Rius, José M. ${ }^{a}$. «La potestat normativa del municipi català medieval». En Miscelllània Ramon d'Abadal. Barcelona: Estudis Universitaris Catalans, 1994, pp. 131-164.

Font Rius, José M.a. Cartas de población y franquicia de Cataluña. 2 vols. Madrid-Barcelona: Consejo Superior de Investigaciones Científicas, 1969-1983.

Furió, Antoni. «Organització del territori i canvi social al País Valencià després de la conquesta cristiana». En Territori i Societat a l'Edat Mitjana. Lleida: Universitat de Lleida, 1997, t. I, pp. 131-166.

Fuster, Joan. Nosaltres els valencians. Barcelona: Edicions 62, 1962. 
DE LOS FUEROS LOCALES AL FUERO DE VALENCIA EN EL MARCO DEL PROCESO DE INSTAURACIÓN DE LA SOCIEDAD FEUDAL DEL SIGLO XIII EN EL REINO DE VALENCIA

García Edo, Vicent. «Adopció del fur de València per la vila de Vila-Real a les Corts Generals del Regne de 1329-1330». En Miscelánea homenaje a J. M. Doñate. Vila-Real: Ajuntament de Vila-Real, 1993, pp. 195-215.

García Edo, Vicent. "Aragón contra Valencia: la disputa foral durante el reinado de Pedro III de Aragón». En Agost, Rosa y Gimeno, Lluís (eds.). Homenatge a Germà Colón Domènech. Castelló: Universitat Jaume I, 2014, pp. 65-102.

García Edo, Vicent. «Blasco de Alagón». Boletín de la Sociedad Castellonense de Cultura, 1986, vol. LXII, pp. 383-420.

García Edo, Vicent. «El Privilegium Magnum del rey Pedro I como acta de salvaguarda del reino de Valencia frente a las intromisiones aragonesas de 1283». Revista Valenciana d'Estudis Autonòmics, 2015, vol. 60, pp. 10-62.

García Edo, Vicent. "La carta de poblament de 1233 i el fur general de Morella». Papers dels Ports de Morella, 2002, vol. 1, pp. 92-94.

García Edo, Vicent. «Nuevas aportaciones documentales sobre don Blasco de Alagón». Boletín de la Sociedad Castellonense de Cultura, 1989, vol. LXVI, pp. 287-301.

García Edo, Vicent. "Origen i expansió dels Furs o Costum de València, durant el regnat de Jaume I». Boletín de la Sociedad Castellonense de Cultura, 1993, vol. 69, pp. 175-200.

García Edo, Vicent. "Orígenes del derecho foral valenciano». Revista Valenciana d'Estudis Autonòmics, 2008, vol. 51, pp. 147-161.

García Edo, Vicente. «El parentesco entre las costumbres de Lérida (1228), Valencia (1238) y Tortosa (1273)». Anuario de Historia del Derecho Español, 1997, vol. 67, pp. 173-188.

García Edo, Vicente. «Els orígens del dret municipal al Regne de València (1232-1284)». En SERRAno Daura, Josep (coord.). Actes de les Jornades d'Estudi sobre el municipi abans de la Nova Planta (1716). El cas de la Fatarella. Tarragona: Diputació de Tarragona, 2013, pp. 189-204.

García Edo, Vicente. «La Carta Puebla de 1233 y el Fuero General de Morella». En El fuero de Laredo en el octavo centenario de su concesión. Santander: Universidad de Cantabria, 2001, pp. 587-605.

García Edo, Vicente. «La redacción y promulgación de la "Costum" de Valencia». Anuario de Estudios Medievales, 1996, vol. 26, n.o 2, pp. 713-728.

García García, Honori. "Los Fueros de Valencia y la "Costum" de Tortosa». Boletín de la Sociedad Castellonense de Cultura, 1933, vol. XIV, pp. 326-332.

García González, Juan. «Las fuentes de los fueros de Valencia». En En torno al 750 aniversario. Valencia: Generalitat Valenciana, 1989, t. 1, pp. 345-360.

García Sanz, Arcadi y García Edo, Vicent. La carta pobla de Vila-real (20 de febrer de 1274). Vila-Real: Ajuntament de Vila-Real, 1995.

García SAnZ, Arcadi. «El jurista Pere Albert i la seva obra». En Estudis històrics i documents dels arxius de protocols del Col.legi de Notaris de Barcelona, 1996, pp. 7-38.

García SAnz, Arcadi. «La concordança de les Costums de Tortosa i els Furs de València». En Costums de Tortosa. Estudis. Tortosa: UNED, 1979, pp. 289-325.

García Sanz, Arcadi. "Las "Consuetudines ilerdenses" y los "Furs" de Valencia». Boletín de la Sociedad Castellonense de Cultura, 1965, vol. XLI, pp. 1-26.

García SAnZ, Arcadi. «Les fonts del dret valencià i les corts forals». En Les Corts Forals Valencianes: poder i representació. Valencia: Generalitat Valenciana, 1994, pp. 38-65.

Garcia-Oliver, Ferran. Terra de feudals. El País Valencià en la tardor medieval. València: Institució Alfons el Magnànim, 1991.

González Antón, Luis. Las Uniones aragonesas y las Cortes del reino. Madrid: Conejo Superior de Investigaciones Científicas, 1975.

Gual Camarena, Miguel. «Contribución al estudio de la territorialidad de los fueros de Valencia». Estudios de Edad Media de la Corona de Aragón, 1947-1948, vol. 3, pp. 262-289. 
Guichard, Pierre y SÁnchez Adell, José. «La carta puebla de Benimahomet y el poblamiento de Castellón en el siglo XIII». Boletín de la Sociedad Castellonense de Cultura, 1984, vol. LX, pp. 352-370.

Guinot Rodríguez, Enric. «El problema de la renta feudal y los fueros. Un análisis de las cartas puebla del siglo XIII en el norte de Castellón». Saitabi, 1983, vol. XXXIII, pp. 59-83.

Guinot Rodríguez, Enric. «El repartiment feudal de l'Horta de València al segle xiIr: jerarquització social i reordenació del paisatge rural». En Guinot Rodríguez, Enric y TorRó, Josep (eds.). Repartiments medievals a la Corona d'Aragó: segles XII-XIII. València: Universitat de València, 2007, pp. 111-196.

Guinot Rodríguez, Enric. «Fueros y ordenamientos jurídicos locales en la Valencia medieval». Revista de Historia Jerónimo Zurita, 2004, vol. 78-79, pp. 203-227.

Guinot Rodríguez, Enric. «La implantació de la societat feudal al País Valencià del segle XiII: la gènesi de les senyories i l'establiment de les terres». En Sabaté i Curull, Flocel y Farré, Joan (coords.). El temps i l'espai del feudalisme. Lleida: Pagès Eds., 2004, pp. 421-442.

Guinot Rodríguez, Enric. «La Orden de San Juan del Hospital en la Valencia medieval». Aragón en la Edad Media, 1999, vol. 14-15, pp. 721-742.

Guinot Rodríguez, Enric. Cartes de poblament medievals valencianes. Valencia: Generalitat Valenciana, 1991.

Guinot Rodríguez, Enric. Els limits del Regne. El procés de formació del País Valencià medieval (1238-1500). València: Institució Alfons el Magnànim, 1995.

Guinot Rodríguez, Enric. Los valencianos de tiempos de Jaime I. Valencia: Ed. Tirant lo Blanc, 2011.

Iglesia Ferreirós, Aquilino. «Las Costums de Tortosa y los Fori/Furs de Valencia». En Costums de Tortosa. Estudis. Tortosa: UNED, 1979, pp. 119-286.

Iranzo, M. ${ }^{a}$ Teresa. «La formación del Derecho local de Huesca y los fueros de Aragón». Aragón en la Edad Media, 1989, vol. 8, pp. 337-350.

Laliena Corbera, Carlos. «La metamorfosis del Estado feudal. Las estructuras institucionales de la Corona de Aragón en el periodo de expansión (1208-1283)». En Sesma Muñoz, José A. (coord.). La Corona de Aragón en el centro de su historia, 1208-1458: la monarquía aragonesa $y$ los reinos de la corona. Zaragoza: Universidad de Zaragoza, 2010, pp. 67-98.

Lalinde Abadía, Jesús. Los Fueros de Aragón. Zaragoza: Librería General, 1976.

Ledesma Rubio, M. a Luisa. "Las "cartas de población" medievales como fuentes de investigación». En II Jornadas de metodología de la investigación cientifica sobre fuentes aragonesas. Zaragoza: 1987, pp. 125-168.

Ledesma Rubio, M. ${ }^{\text {a Luisa. } ~}$ Las cartas de población aragonesas y su remisión a los fueros locales: La problemática del fuero de Zaragoza». Ius fugit: Revista Interdisciplinar de Estudios Histórico-jurídicos, 1992, vol. 1, pp. 63-78.

Ledesma Rubio, M. a Luisa. Cartas de población del Reino de Aragón en los siglos medievales. Zaragoza: Institución Fernando el Católico, 1991.

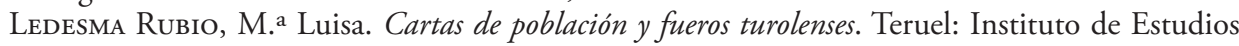
Turolenses, 1988.

López Elum, Pedro. «La conquista de Valencia». En Història del País Valencià. Barcelona: Edicions 62, 1989, vol. 2, pp. 57-124.

López Elum, Pedro. «La costum, els furs y las cortes». En Jaume I, legislador. El reino de Valencia. Valencia: Generalitat Valenciana, 2008, pp. 167-182.

López Elum, Pedro. Los orígenes de los Furs de València y de las Cortes en el siglo XIII. Valencia: Biblioteca Valenciana, 2001.

Martínez DíEz, Gonzalo. «Los fueros valencianos en relación con otros fueros coetáneos». En En torno al 750 aniversario. Valencia: Generalitat Valenciana, 1989, t. 1, pp. 379-394. 
DE LOS FUEROS LOCALES AL FUERO DE VALENCIA EN EL MARCO DEL PROCESO DE INSTAURACIÓN DE LA SOCIEDAD FEUDAL DEL SIGLO XIII EN EL REINO DE VALENCIA ENRIC GUINOT RODRÍGUEZ

Mateu Beltrán, César. La carta de poblament de Xodos: documentació, història i usos socials del català al País Valencià des de l'Edat Mitjana fins al segle XX. Trabajo final de carrera. Edición electrónica: Barcelona: Universitat Oberta de Catalunya, 2011.

Montagut, Tomàs de. «Comunidades locales en Cataluña y su derecho medieval». Vasconia: Cuadernos de historia-geografía, 2009, vol. 36, pp. 5-18.

Montagut, Tomàs de. "Derecho municipal y derecho común: el caso de Cataluña». En Serna, Margarita y BARÓ, Juan (coords.). El fuero de Laredo en el octavo centenario de su concesión. Santander: Universidad de Cantabria, 2001, pp. 517-534.

Montagut, Tomás de. «Les universitats de les ciutats i viles medievals de Catalunya i el seu dret: dels usos, costums, privilegis i llibertats a les ordinacions municipals». En Serrano Daura, Josep (coord.). Actes de les Jornades d'Estudi sobre el municipi abans de la Nova Planta (1716). El cas de la Fatarella. Tarragona: Diputació de Tarragona, 2013, pp. 25-38.

Montagut, Tomàs de. «Ordenamientos jurídicos locales catalanes». Revista de Historia Jerónimo Zurita, 2003-2004, vol. 78-79, pp. 153-178.

Morales, Jesús. «La formación bajomedieval del sistema aragonés de fueros y observancias». En La Corona de Aragón en el centro de su historia: 1208-1458: la monarquía aragonesa y los reinos de la Corona. Zaragoza: Universidad de Zaragoza, 2010, pp. 353-394.

Morales, Jesús. Fueros y libertades del Reino de Aragón: de su formación medieval a la crisis preconstitucional (1076-1800). Zaragoza: Rolde de Estudios Aragoneses, 2007.

Navarro Espinach, Germán. «Los fueros de Aragón en la repoblación valenciana». En Los fueros de Teruel y Albarracin: Actas de las Jornadas (1998). Teruel: Instituto de Estudios Turolenses, 2000, pp. 59-75.

Peñarroja, Leopoldo. Cristianos bajo el Islam. Los mozárabes hasta la reconquista de Valencia. Madrid: Gredos, 1993.

Peset Reig, Mariano. «De nuevo sobre la génesis de los fueros de Valencia». Anales del Seminario Metropolitano de Valencia, 1971, vol. 16, pp. 395-413.

Peset Reig, Mariano. «Furs de Valencia: su sentido y vigencia». En En torno al 750 aniversario. Valencia: Generalitat Valenciana, 1989, t. 1, pp. 361-378.

Peset Reig, Mariano. «Observaciones sobre la génesis de los fueros de Valencia y sobre sus ediciones impresas». Ligarzas, 1971, vol. 3, pp. 47-84.

Reglà, Joan. «El dualismo en Valencia y sus desequilibrios». Saitabi, 1967, vol. XVII, pp. 51-70.

Reglà, Joan. Aproximació a la història del País Valencià. Valencia: L'Estel, 1968.

Romeu Alfaro, Sylvia. «Los fueros de Valencia y los fueros de Aragón: la jurisdicción alfonsina». Anuario de Historia del Derecho Español, 1972, vol. 42, pp. 75-115.

Torró, Josep. «Guerra, repartiment i colonització al regne de València (1248-1249)». En Guinot Rodríguez, Enric y Torró, Josep (eds.). Repartiments medievals a la Corona d'Aragó: segles XII-XIII. València: Universitat de València, 2007, pp. 197-270.

Torró, Josep. «Jaume I i la formació del regne de València. Una perspectiva general». En Colón, Germà y Martínez Romero, Tomàs (eds.). El rei Jaume I. Fets, actes i paraules. CastellóBarcelona: Fundació Germà Colón-Abadia de Montserrat, 2008, pp. 13-32.

Torró, Josep. «Jaume I: el temps de les grans conquestes (1213-1276)». En Belenguer, Ernest (dir.). Història de la Corona d'Aragó. Barcelona: Edicions 62, 2007, vol. I, pp. 117-122.

Torró, Josep. El naixement d'una colònia. Dominació i resistència a la frontera valenciana (12381276). València: Universitat de València, 1999.

Torró, Josep. La formació d'un espai feudal. Alcoi de 1245 a 1305. València: Diputació de València, 1992.

Ubieto Arteta, Antonio. Orígenes del Reino de Valencia. Valencia: Editorial Anúbar, 1975-1977, 2 vols. 